\title{
Mathematical Doctoral School of the Mathematical Seminar of the University of Debrecen at the beginning of the 20th century (Debrecen, 1927-1940)
}

\author{
TÜNDE KÁNTOR
}

Abstract. In this article, we present the life and carrier of Professor Lajos Dávid, and those 16 mathematical dissertations, along with their authors, which were written under the supervision of Professor Dávid between 1927 and 1940. At the time mentioned, Lajos Dávid was the leader of the Mathematical Seminar of the University of Debrecen. The themes of the dissertations were connected with his scientific work, such as the history of mathematics (the two Bolyais), or his research work in mathematical analysis (arithmetic-geometric mean).

Key words and phrases: Lajos Dávid, the Doctoral School of the Mathematical Seminar of the University of Debrecen, Dissertationes Davidianae (1927-1940),presentation about the authors of the dissertations (Springer I, Jankó A, Csada I, Vajnóczky I, Hittrich J, Jelitai J, Barna B, Bujdosó E, Tardos V, Szilágyi I, Keresztesi M, Zigány F, Szénássy B, Hárs J, Gáspár Gy, and Kárteszi F.).

ZDM Subject Classification: A30.

The Leader of the Mathematical Doctoral School of the Mathematical Seminar of the University of Debrecen: Lajos Dávid

(Kolozsvár, 1881-Leányfalu, 1962)

University professor, Bolyai researcher

The Dávid family came from Transylvania. Lajos Dávid himself was educated at Kolozsvár, attending first the elementary school of the Reformed 
College. He graduated in 1889, and then studied at the Mathematics and Science Faculty of the University of Kolozsvár, where he undertook research for his doctorate under the supervision of Lajos Schlesinger and submitted his thesis The Gauss-type medium arithmetico-geometricum in 1903. He received his doctoral degree, as well as a secondary school teaching certificate in mathematics and physics in 1904. Between 1903 and 1904 he worked as a trainee teacher, then as a substitute at the National College in Kolozsvár. In 1904-1905 he undertook his military service. Between 1905 and 1906 Dávid studied in Göttingen, and then in Paris. Returning to Hungary, he first became an associate teacher at the Unitary College of Kolozsvár (1906-1907), and was later appointed to be a teacher at the Reformed College of Székelyudvarhely (1908-1912). He habilitated at the University of Kolozsvár in 1910, with his thesis About the Theory of Algebraic Numbers and Functions. To give lectures at the university, he had to commute between Székelyudvarhely and Kolozsvár, thus he desired to become a teacher in a university town, which he only achieved somewhat later. In 1911, Lajos Schlesinger (a Professor in Giessen) invited him to take part in writing commentaries on the works of Gauss for the Mathematics Seminars in Göttingen and Giessen. In 1914, he filled a vacancy, which had occurred for a substitute teacher at the Higher Vocational School of the 8th District of Budapest, so he moved to the Hungarian capital. He was known to be accurate, scrupulous and ambitious in his work. He possessed professional skills and was a devoted teacher. His work was highly efficient, and he was held in high esteem both by his colleagues and his pupils. He gave several lectures at the sessions of the Society of Mathematics and Physics. In 1916, on the recommendation of Lipót Fejér and Manó Beke, the University of Budapest supported his habilitation as private professor in analysis. In 1918, he was the first to give lectures at the university on the history of mathematics, focusing on the history of analysis. Between 1919 and 1929 he worked as a professor of the so-called "Paedagogium", the Teacher Training College of state civil schools in Budapest. He became engaged in the study of different issues of education and dealt with educational reforms. It was during this time that he had his interest awakened in research into the two Bolyais. Today Dávid is best known for his work as a devoted Bolyai researcher. His most significant book, entitled The life and work of the two Bolyais was published in 1923. Based on this book, he had several articles about the two Bolyais, which he intended to be distributed abroad. As early as 1924, Lajos Dávid pointed out that the work of János Bolyai contained the seeds of the theory of relativity. Besides, the writing of Lajos Dávid is an important source-book because of the 
accuracy of its data. A second edition of this book was published in 1979, that is, 17 years after his death.

Dávid (Figure 1) was a dedicated professional in teacher training. From 1925 on, he worked as a lecturer in mathematics at the University of Debrecen, where he became a public associate professor and the first leader of the Mathematical Seminar within the framework of the Faculty of Arts of the University of Debrecen in 1929, and a full professor in 1933 (until 1940). His focus again shifted to the study of arithmetic and geometric means, the history of mathematics, the Bolyai research, and the popularization of mathematics. The first research group in the history of mathematics in Hungary was established under his guidance (with members such as Springer I, Csada I, Bujdosó E, Woyciechowsky (Jelitai) J, Keresztesi M, Szénássy B, Hárs J). Apart from organising the first Mathematical Seminar (an Institute) in Debrecen he was also launching an institute library, and training the next generation of researchers with academic degrees.

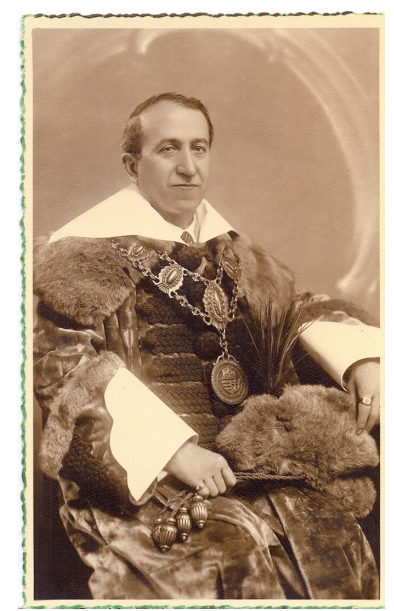

Figure 1. Lajos Dávid as Dean of the Faculty of Arts (1935)

16 doctoral theses were written under his guidance. Many of the topics concerned related to Dávid's projects: to the research of the Bolyais and to the Gauss-type 'medium arithmetico-geometricum'. The dissertations were published as individual books, all of them written in Hungarian, with German title and summary, in the series titled Publications of the Mathematical Seminar of the University of Debrecen (1927-1940, booklets No. I-XV.). Later, 15 of them were collected in a colligation under the title Dissertationes Davidianae Debrecen 
1927-1940. We have to mention that the dissertation of Ferenc Kárteszi (1933) was left out from this colligation because of the financial crisis of 1933. It is contained in the collection of the University Library, Debrecen, where it is preserved among the dissertations of Doctors of Philosophy.

There were only a few to assist Dávid at the Mathematics Seminar, thus Dávid himself held lectures on a very wide variety of topics: descriptive geometry, infinite series, infinitesimal calculus and geometry, analysis, the practical solution of equations, the theory of differential equations, surface theory, probability theory, and practical mathematics. To help effective learning, he wrote course books, e.g., Practical Differential Geometry I, and Plane Curves. He also held lectures for medical students. He was very well liked by his students. He delivered his entertaining lectures in a vivid and familiar style.

He assigned significance to mathematical applications, both the mechanical and economical aspects. Also when there was no teaching at the university, he kept in touch with his students and accompanied them on trips, or received them at his home and replied to their letters during the summer vacations.

In addition, he dealt with the didactics of mathematics on an academic level, and he delivered lectures at the Teacher Training Institute of the University Debrecen, as well. He was of the belief that "a professor should not only be convinced in what he professes, but, at the same time, he should also be able to make his students be convinced of that, too, that is, a professor should be a real teaching master". He was the dean of the Faculty of Arts in 1934/35 and pro-dean in the next year, and was also member of the teachers' commission of enquiry, and a government delegate on the occasion of secondary-school graduation exams. He wrote some essays on reforms concerning teaching in secondary schools, emphasizing the close affinity of people to what is concrete as a natural guiding principle in the process of forming secondary-school education.

Between 1940 and 1944, he worked as a professor and director of the Institute of Mathematics at the University of Kolozsvár, Transylvania. During this time, he wrote his book entitled Bolyai Geometry on the Basis of the Appendix, a good many copies of which were later pulped, and only a few copies have survived. In 1944, he returned to Hungary, but after this he became neglected, did not get any respected position, nor the qualification consonant with his scientific reputation. He was not awarded the Degree of Doctor of Science. He worked at the Institute of Geophysics, then at the National Museum. In 1950 he was forced into retirement. On the 150th Anniversary of the birth of János Bolyai his books were not exhibited. He went on with studying his favourite subject, the Bolyai 
research, with the help of his godson László Kalmár, but at the Mathematics Congress in 1960 he only participated as a member of the audience. Posterity remembers him as one of the most eminent Bolyai researchers. He published 55 publications, and left behind 10 more, unpublished.

His major works:

1. The algorithm of Gauss's geometrical and arithmetical mean and the theory of its generalization (in Hungarian), Mathematikai és Physikai Lapok 15 (1900) 10-23, 132-151.

2. To the theory of algebraic iteration (in Hungarian), Mat. és Termtud. Ért. 25 (1907) 319-325.

3. Theorie des Gauss'schen verallgemeinerten und speziellen arithmetischgeometrischen Mittels, Mat. und Naturwiss. Ber. aus Ungarn 25 (1907), $152-171$.

4. Zur Theorie der algebraischen Iteration, Mat. und Naturwiss. Ber. aus Ungarn 25 (1909) 172-177.

5. Reihenentwicklungen und Konvergenzuntersuchungen betreffend die Schapirasche Iteration, Journal für die reine und angewandte Mathematik 140 (1911) 277-296.

6. Zur Gauss'schen Theorie der Modulfunktion, Rendiconti del Circolo Mathematico di Palermo 35 (1913) 82-89.

7. Farkas Bolyai and the reform of the instruction of mathematics (in Hungarian) Magyar Pedagógia 30 (1921) 148-156.

8. The life and work of the two Bolyais (in Hungarian) Bp. (1923), pp 202; 2nd Enhanced Edition, Gondolat (1979), pp. 335.

9. Mathematicians from Debrecen in the old times (in Hungarian), A debreceni Tisza István Tud. Társaság II. Oszt. Munkái 2 (1927) 4, 35-54.

10. The Bolyai geometry on the basis of the Appendix (in Hungarian) Minerva, Kolozsvár (1944), pp. 188; Reprint, Bolyai János Katonai Müszaki Főiskola, Bp. (1992) pp. 192.

\section{Dissertationes Davidianae (Debrecen 1927-1940)}

Lajos Dávid collected 15 dissertations, and published them under the title Dissertationes Davidianae Debrecen 1927-1940. Nowadays, this colligation can be found in the Library of the Mathematical Institute of the University of Debrecen (inventory number: 387). We have to mention that it does not contain the 16th 
dissertation, that of Ferenc Kárteszi, which is a consequence of the financial crisis of 1933. It can be found among the dissertations of Doctors of Philosophy, in the Library of the University of Debrecen (DEK 10:8, 5675), entitled On the ten conics determined by six points of a conic and the configurations connected with them.

The 15 dissertations are as follows (Figure 2):

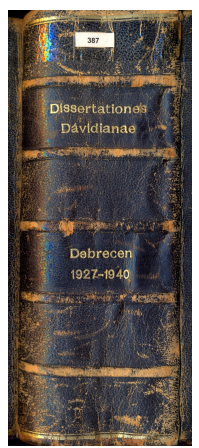

Figure 2. Dissertationes Davidianae (1927-1940)

I. Springer, István: A supplement to the axiomatic of János Bolyai's geometry, Bp. (1927).

II. Jankó, Antal: The medium aritmetico-geometricum in the case of quaternions, Pécs (1928).

III. Csada, Imre: Farkas Bolyai's equivalents of the 5th postulate, Sárospatak (1929).

IV. Vajnóczky, István: Mathematics in the system of Ákos Pauler, Debrecen (1929).

V. Hittrich, József: Volume and smooth radiation, Bp. (1932).

VI. Woyciechowsky (Jelitai), József: The life and mathematical work of Pál Sípos, Bp. (1932).

VII. Barna, Béla: To the theory of the arithmetic and geometric mean, Debrecen (1932).

VIII. Bujdosó Ernö: The didactics of mathematics in Farkas Bolyai's works, Szeghalom (1934).

IX. Tardos, Vida: On singular points of space-curves, Pannonhalma (1934).

X. Szilágyi, Imre: Iteration of mean-valued functions, Debrecen (1935). 
XI. Keresztesi, Mária: A history of the Hungarian mathematical language, Debrecen (1935).

XII. Zigány, Ferenc: On conform representations of curve surfaces, Debrecen (1935).

XIII. Szénássy, Barna: Infinitesimal thoughts of Farkas Bolyai, Debrecen (1937).

XIV. Hárs, János: The Arithmetic of Debrecen, Sárospatak (1938).

XV. Gáspár, Gyula: Generalization of infinite groups of permutations, Debrecen (1940).

The Life and Carrier of the Mathematical Doctors, and a short rewiew of the dissertations

1. István Sályi (Springer) (Budapest, 1901-Miskolc, 1974)

Mechanical engineer, professor, Doctor of Mechanical Sciences

István (Springer) Sályi was the first doctor to write a dissertation in mathematics at the University of Debrecen. He was awarded the doctor's degree at an Honorary Doctoral Awarding Ceremony (Promotio sub auspiciis Gubernatoris). Prior to that, he held a diploma of mechanical engineering, supplemented with studies of mathematics in Debrecen.

He submitted his dissertation A supplement to the axiomatic of János Bolyai's geometry in 1927. In some sections of the Raum-Lehre, János Bolyai provided step-by-step verification that the ring is identical with circles, and also his new concept that the plane and the ring are suitable notions to build a rigorous geometry on was also mentioned. This question was thoroughly investigated by István Springer, who concluded that although this idea of János Bolyai is fertile, the axioms presented in the Raum-Lehre are insufficient for a perfect construction of geometry and have to be complemented with some axioms of congruence and continuity.

István Sályi wrote also another dissertation at the Technical University of Budapest, entitled Slow change of form in concrete. He received the degree of Technical Doctor in 1936, and within three years, he did his habilitation. When the Technical University of Miskolc was founded in 1949, he became a professor, and a little later, the rector of the University of Miskolc (1950-1961). He introduced education reforms at the Technical University, and became the author of many university lecture-books. His was an excellent lecturer, but recognized the importance of practical application as well, and, together with Gusztáv Fáber, 
he wrote the famous Problems in Statics. He established the so-called Sályi Mechanical School, as well as, an academy research group in Miskolc. He was the president of the Hungarian Committee of IUTAM (International Union of Theoretical and Applied Mechanics). He was also a member of the Hungarian Parliament (1953-1974). An oil portrait of him can be found in the council room of the University of Miskolc.

His major works:

1. A supplement to the axiomatic of János Bolyai's geometry (in Hungarian), Bp. (1927).

2. Statics (in Hungarian), Nehézipari Müszaki Egyetem, Miskolc (1953).

3. Addition to the theory of continuous girders, Acta Technica Hung. 7 (1953) 1-2, 125-146.

4. Problems in statics I-II. (with Gusztáv Fáber) (in Hungarian), Bp. (1957, 1961, 1964).

5. Complex functions in the theory of elasticity (in Hungarian), Nehézipari Müszaki Egyetem Közleményei 2 (1958), 5-28.

2. Antal Jankó (Budapest, 1901-Budapest, ??)

Teacher of mathematics and physics

He studied at the University of Debrecen and obtained a teacher's diploma in mathematics and physics. Finishing his studies, he taught at several schools in Budapest, including ones where Ferenc Zigány and József Hittrich worked. He made his doctorate in Debrecen.

In his dissertation The medium aritmetico-geometricum in the case of quaternions, he dealt with a theme promoted by Lajos Dávid, in particular, with the case of quaternions. He had no more publication.

3. Imre Csada (Hódmezövásárhely, 1884 - Budapest, 1955)

Teacher of mathematics and physics, headmaster of the Teacher Training Institute

He studied at University of Debrecen and received his doctor's degree in 1929. In his dissertation entitled Farkas Bolyai's equivalents of the 5th postulate, he examined the substitute postulates listed by Farkas Bolyai, trying to answer the question how to rank them in regard to simplicity.

Nowadays, we use the following substitute axiom: "Three points are either on a straight line or a circle." I. Csada was appointed to be the director of the 
Teacher Training Institute in Cinkota (1929-1938), and from 1938 in Budapest. Later his attention turned to the teaching of physics: he wrote exercise books for children aged 14-18, and a plenty of didactical articles. He made a very simple instrument to make the teaching of singing easier.

4. István Vajnóczky (Máramarossziget, 1882-Debrecen, 1931) Teacher of mathematics and physics, Piarist priest

Vajnóczky studied at the University of Kolozsvár and got his diplomas as a teacher of mathematics and physics, and as a Catholic priest. He taught in the Piarist Secondary Schools of several towns (Budapest, Debrecen, Kecskemét) between 1904 and 1931. He was an excellent teacher.

He wrote his dissertation in 1929 under the title Mathematics in the system of Ákos Pauler. In his dissertation, Vajnóczky presented the development of mathematics and analysed the subject and main divisions of philosophy.

He delivered lectures at the Teacher Training Institute of the University of Debrecen, his subject was called "Infinitesimal Calculus".

5. József Hittrich (Komárom, 1890-Budapest, 1962)

Headmaster, teacher of mathematics and physics, inspector of mathematics

He obtained a teacher's diploma in mathematics and physics at the University of Budapest in 1913.

In his dissertation entitled Volume and smooth radiation, which he finished in 1931, he dealt with the Poisson problem of probability, and with the connections between some theorems of the theory of surfaces and those of the uniform distribution of radiation.

Later he wrote some articles, became a teacher and the headmaster of the Secondary School of the 8th District of Budapest. He established the Secondary School for Workers (1945), which was the first of its kind. He was awarded with the Yad Vashem Prize.

6. József Jelitai (Woyciechowsky) (Budapest, 1899-Budapest, 1944)

Teacher of mathematics and physics, historian of mathematics, honorary lecturer

His family was of Polish origin. He studied at University of Budapest, then took his doctoral exams at the University of Debrecen. 
His dissertation The life and mathematical work of Pál Sipos (Figure 3) is considered to be his major work, which is, nowadays, also the most popular among his works. Sípos was in search of a solution for the problem of squaring a circle, he achieved some remarkable results in the field of constructions using a straightedge, a compass and a ruler with transcendental curve for edge. His main findings can be read in a study preserved in the collection of manuscripts of the Hungarian Academy of Sciences, and in a paper published in the journal Acta of the Berlin Academy. In these papers, Sípos defined the cochleoid, already described in Euler's work, with the help of which he also designed a construction for the rectification of the ellipse. Sípos's approximation formula was studied by József Jelitai, who compared its accuracy with nearly fifty formulae of later dates. His findings were very favourable for Sípos's procedure for the extreme cases, and also when compared to the values obtained from the complete elliptic integral of the second kind. Jelitai found only two formulae which proved to be more accurate than the one of Sípos, and Sípos's formula can be regarded as accurate up to the term of the 8th degree. On pages 101-110 of the dissertation, there is a German abstract containing unpublished letters of Professor Bode and Kästner.

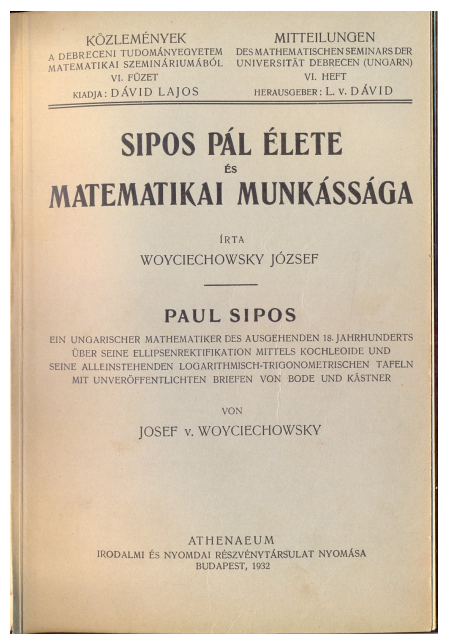

Figure 3. Jelitai's dissertation (1932)

Jelitai was an honorary professor of the University of Debrecen (1938), as well as, of the University of Budapest (1942). He wrote a lot of articles about the history of mathematics and astronomy in Hungary. He dealt with the Hungarian 
connections of the Bernoullis, and he was the one to discover János Bolyai's passport in Nagyszeben with his description.

He died in the autumn of 1944 in a traffic accident.

His major works:

1. The life and mathematical work of Pál Sípos (in Hungarian), Bp. (1932).

2. Pál Sípos's manuscript and the cochleoid (in Hungarian), Mat. és Fiz. Lapok 41 (1934), 45-54.

3. Sípos's manuscripts in the Teleki archives (in Hungarian), Mat. és Fiz. Lapok 42 (1935), 134-138.

4. Daniel and Johann Bernoulli in the contemporary travel-diaries and letters of Teleki (in Hungarian), Mat. és Fiz. Lapok 43 (1936), 142-160.

5. Zur Geschichte der Mathematik in Ungarn, Archeion 18 (1936), 350-354.

6. Clairaut, La Condamine, d'Alembert, and their contemporaries in the traveldiaries of Teleki (in Hungarian), Mat. és Fiz. Lapok 44 (1937).

7. To the portrait of Farkas Bolyai (in Hungarian), Mat. és Fiz. Lapok 45 (1938).

8. Archives data on the history of astronomy in Hungary (in Hungarian), Csillagászati Lapok 1 (1938) 3-4, 2 (1939) 1-2.

7. Béla Barna (Máramarossziget, 1909-Debrecen, 1990)

Professor, Doctor of Mathematical Sciences

Béla Barna came from a teacher family. He studied mathematics, physics and chemistry at first at the University of Budapest, but later he switched to Debrecen and there he obtained a teacher's diploma in 1931. He made his doctorate in 1932 under Lajos Dávid, in the field of arithmetic and geometric means.

His dissertation To the theory of the arithmetic and geometric mean begins with a summary of the main results already achieved, while in the second part, he states new theorems and describes their proofs.

He lectured on Number Theory at the University of Debrecen without salary until 1935, later taught at various secondary schools. During the Second World War, he was a soldier and a prisoner of war. In 1951, he joined the staff of the University of Debrecen. In 1967, he became a Doctor of Mathematical Sciences. He was professor at the Teachers College in Eger, as well, and for a long time, the managing editor of Publicationes Mathematicae (Debrecen).

He had two areas of scientific interest: the theory of mean values; and the theory of iteration, the zeros of functions. He wrote 14 scientific publications 
and two lecture-books. His first publications appeared in journals of rank, for example, in the Journal f. d. r. u. angew. Math. With his activity in the field of the theory of iteration, he preceded his age: books written on the theory of iteration today refer to his work as the groundwork.

His major works:

1. To the theory of the arithmetic and geometric mean (in Hungarian), Debrecen (1932).

2. Über die Divergenzpunkte des Newtonschen Verfahrens zur Bestimmung von Wurzeln algebraischer Gleichungen I-IV, Publ. Math. Debrecen 3 (1953), 109-118, 4 (1956) 384-397, 8 (1961), 193-207, 14 (1967), 91-97.

3. Über die Iterationen realler Functionen I-III, Publ. Math. Debrecen 7 (1960), 16-40, 13 (1966), 169-172, 22 (1975), 269-278.

8. Ernő Bujdosó (Debrecen, 1908-Debrecen, 2001)

Teacher of mathematics and physics, teacher of history, Professor of the Teacher Training Institute, inspector of physics

He studied at the University of Debrecen, and received a one-year stipendium at the University of Munich in 1930. He made his doctorate under Lajos Dávid's supervision, in 1934.

In his dissertation The didactics of mathematics in Farkas Bolyai's works, he analysed Farkas Bolyai's modern pedagogical principles on the ground of Farkas Bolyai's Elements of Arithmetics (1830).

He taught in several secondary schools (Szeghalom, Pápa, and Debrecen). He was a very excellent teacher. Later he dealt with the teaching of physics, and became an inspector of physics and a professor of the Teacher Training Institute of Debrecen. He wrote some articles connected with new pedagogical methods and with the history of teaching physics.

His major works:

1. The didactics of mathematics in Farkas Bolyai's works (in Hungarian), Szeghalom (1934).

2. The work of the physicist Irén Károly (in Hungarian), Fizikai Szemle X No. 1 (1960), 3-6. 
9. Vida Tardos (Fillinger) (Szepesbéla, 1907-Kunszentmárton, 1963) Teacher of mathematics and physics, professor of the Teacher Training Institute, Piarist priest, forest engineer

As a student, he joined the Piarist Order. He was very good in mathematics: he even won the first prize in 1928 with his essay on a problem posed by Professor Lipót Klug. His essay was published in the Hungarian Mathematical and Physical Journal for Secondary Schools (1928). He studied at the College of Theology in Pannonhalma (1926-1931), and later at the University of Budapest (1932-1933), where he got a teacher's diploma in mathematics and physics.

In 1934, he wrote his doctoral thesis at the University of Debrecen. The topic of this work, entitled On singular points of the space-curves, belongs to differential geometry.

From 1931 on, he taught at several Piarist Secondary Schools, and also at the College of Theology, Pannonhalma. As a consequence of the political situation, he left the clergy. After this, he was the manager of the forestry of Pannonhalma and the estates of Bakonybél, and later became a priest in Vác and Kiskunfélegyháza. After the nationalization of the schools, he taught in Tiszaföldvár and in Kengyel. In 1956 he took part in the revolution with his pupils. For this, he suffered degradation. He died lonely.

\section{Imre Szilágyi (Karcag, 1911-??)}

Teacher of mathematics and physics

No essential information is available on him, only some fragments of his life can be depicted. He studied at the University of Debrecen and obtained teacher's diploma in mathematics and physics.

The theme of his dissertation Iteration of mean-valued functions (1935) was one of Dávid's themes, and the dissertation was connected to Dávid's work Iteration of mean-valued functions (1909).

11. Mária Keresztesi (Debrecen, 1910-Budapest, 1981)

Teacher of mathematics and physics, Mentor teacher of the Practising Secondary School of the University of Debrecen

She studied at the University of Debrecen and received a teacher's diploma in mathematics and physics in 1933. She made her doctorate in 1935.

In her dissertation entitled $A$ history of the Hungarian mathematical language (Figure 4), she emphasized that Lajos Dávid had a great influence on her choice 
of theme. From 1927 to 1941, she was the only woman who got a doctorate degree in mathematics at the University of Debrecen. In the Preface of her work, she called attention to the importance of language in sciences. The dissertation has two parts: in the first part, she divides the history of mathematics to eight stages and examines them separately. In the second part, she complies a vocabulary (43 pages) on the basis of 120 books and 100 publications.

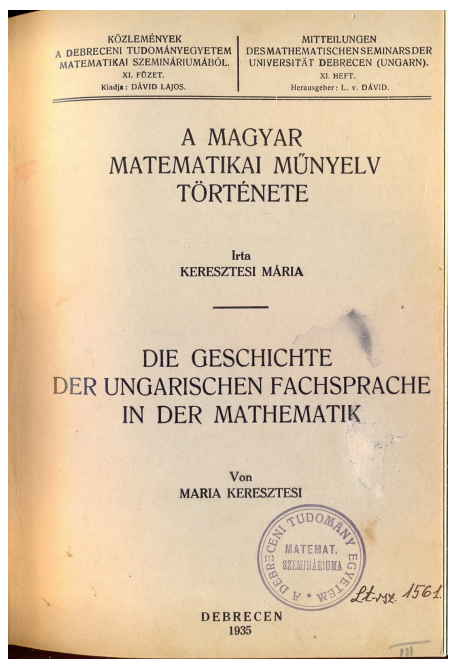

Figure 4. Keresztesi's dissertation (1935)

Between 1934 and 1936, she was a lecturer without salary at the University of Debrecen. After the Second World War, she taught in different Secondary Schools of Debrecen. For a long time, she was a mentor teacher at the Practising School of the University of Debrecen. She wrote some didactical articles.

12. Ferenc Zigány (Budapest, 1895-Budapest, 1975) Professor of the Technical University

He studied mathematics and descriptive geometry at the University of Budapest. In 1914, he won the Eötvös Competition. He got his diploma in 1926, and then taught at the Technical University of Budapest and at Secondary Schools, as well. He made his doctorate in 1935 at the Mathematical Seminar of Lajos Dávid. 
His dissertation On conform representations of curve surfaces was written on conform representation, which at first was a geometrical problem, but later became a method of function theory.

From 1941, Ferenc Zigány was an honorary professor at the Technical University of Budapest, and in 1948 he was appointed as a full professor. He was involved in the teaching of descriptive geometry. He wrote a lot of nice lecture-books with illustrative figures, and was a legendary professor.

His major works:

1. On conform representations of curve surfaces (in Hungarian), Debrecen (1935).

2. The work of Lipót Klug (in Hungarian), Mat. és Fiz. Lapok 50 (1943), 205-222.

3. Descriptive Geometry I-II (in Hungarian), Bp. (1950-51).

13. Barna Szénássy (Ungvár, 1913-Debrecen, 1995)

Professor, Doctor of Mathematical Sciences, historian of mathematics

He studied at the University of Debrecen and obtained his teacher's diploma in mathematics and physics in 1936. He did his research work under the supervision of Professor Dávid. He obtained his doctorate in Debrecen in 1937.

In his dissertation Infinitesimal thoughts of Farkas Bolyai, he examined Farkas Bolyai's thoughts written in the Tentamen. He presented innovations introduced in mathematical analysis by Bolyai, who had preceded contemporary mathematicians.

He taught at different secondary schools (the Piarist Secondary School of Debrecen, the Catholic Secondary School of Gyula and Secondary Schools of Ungvár). He spent the year 1942-43 in Berlin. After military service and captivity, he was a teacher again until 1951. While in captivity, he learnt Russian and dealt with mathematics, too. From 1951 until his retirement in 1977, he worked at the University of Debrecen. He became Doctor of Mathematical Sciences in 1991. In 1994, he was awarded the title of Professor Emeritus.

His main area of interest was the history of mathematics in Hungary. At the Institute of Mathematics of the University of Debrecen, he launched his course "History of Mathematics" for interested students, who were very fond of his lectures and enthusiasm. He wrote 11 books and 65 articles. With two of his books, he won the Award of the Hungarian Academy of Sciences: History of Hungarian Mathematics (1970, 1974) and Farkas Bolyai (1975). 
His major works:

1. Infinitesimal thoughts of Farkas Bolyai (in Hungarian), Debrecen (1937).

2. Gyula König (1849-1913) (in Hungarian), Akadémiai Kiadó, Bp. (1965), pp. 142 .

3. History of Hungarian Mathematics (in Hungarian), Bp. (1970, 1974, 2008).

4. Farkas Bolyai (1775-1856) (in Hungarian), Akadémiai Kiadó, Bp. (1975), pp. 157.

5. History of mathematics in Hungary until the 20th century, Bp.-Berlin, Springer-Verlag, (1992).

14. János Hárs (Bonyhád, 1894-Budapest, 1962)

Teacher of mathematics

He studied at the University of Budapest and got a teacher's diploma. He taught in several Secondary Schools, including the Commercial School of the 8th District of Budapest, from 1929. He wrote his first book in 1936, which is entitled How did Master György of Hungary count in 1499? This work awoke the attention of Dávid, and Dénes König, too, wrote a very nice review on it for the Mathematical and Physical Journal (Vol. 41 (1937), pp. 127-128). Lajos Dávid encouraged Hárs to study the first old Arithmetic written in Hungarian, and in his book Mathematicians from Debrecen in the old times (Debrecen, 1927), he called this Arithmetic The Arithmetic of Debrecen. J. Hárs made his doctorate in 1938, in Debrecen.

The title of his dissertation was The Arithmetic of Debrecen (Figure 5). The dissertation consists of five parts: A historical survey; A review of The Arithmetic of Debrecen (1577); The full original text of The Arithmetic of Debrecen; On the second edition of The Arithmetic of Debrecen and on the third edition, the Arithmetic of Kolozsvár; German abstract. The main value of the dissertation lies in the publication of the original text and in the references on later editions, which are not available in Hungary. Hárs called into question who the author could be. We can agree with his opinion that Rudolph Hoffhalter was not only the printer, but also the author of The Arithmetic of Debrecen. Behind the Hungarian-written text, in many places, we can suspect the rules of Polish word order.

His major works:

1. How did Master György of Hungary count in 1499? (in Hungarian), Bp. (1936). 
2. The Arithmetic of Debrecen (in Hungarian), Sárospatak (1938).

3. Mathematics for Commercial Secondary Schools (in Hungarian), Bp. (1948).

4. Mathematics for Economical Secondary Schools (in Hungarian), Bp. (1949).

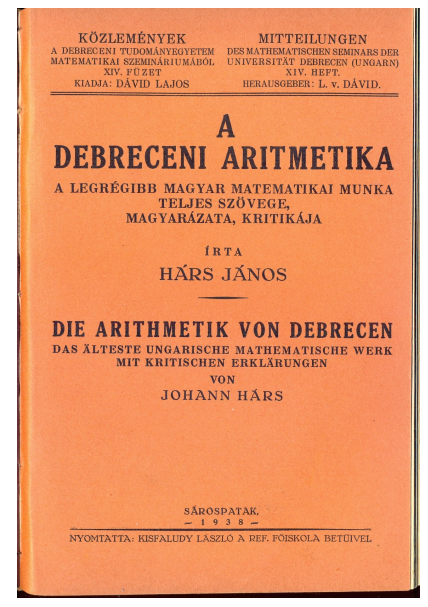

Figure 5. Hárs's dissertation (1938)

15. Gyula Gáspár (Szeged, 1916-Miskolc, 1980)

Professor, Candidate of Sciences

His father was a regional superintendent of schools. He studied at the University of Debrecen, where he finished his studies with a doctorate in 1940 . Then, in 1941, he obtained a teacher's diploma in mathematics and physics. He was a top grade student, it could have been possible for him to get the distinguished promotion by the occasion of an Honorary Doctoral Awarding Ceremony.

In his dissertation Generalization of infinite permutation groups, he discussed two kinds of generalizations of permutation groups, and connected Specht's generalization with infinite permutation groups.

He was an assistant professor at the University of Debrecen between 1938 and 1940. Later in 1940, he followed Professor Dávid to the University of Kolozsvár, where he taught at the Mathematics Institute and at the Practising School of the University. After returning to Hungary for a short period (1945-1947), he stayed again in Kolozsvár as head of the Department of Function Theory at the University. Between 1949 and 1950, he was a secondary school teacher and 
inspector in Budapest. From 1951 he worked at the Department of Mathematics of the Technical University of Miskolc. He became a professor in 1964.

His scientific interests extended to: group theory, the generalization of infinite groups of permutations, matrix theory, and the theory of determinants. $\mathrm{He}$ achieved important results in the field of the axiomatic characterization of function equations system with the help of determinants. He was the author of books and lecture-books, and the editor of the Green Series volumes of Mechanical Mathematics. He published some articles connected with the history of the University of Miskolc.

His major works:

1. Generalization of infinite permutation groups (in Hungarian), Debrecen (1940).

2. Basis of Analysis (in Hungarian), (1952).

3. Matrices (in Hungarian), Müszaki Könyvkiadó, Bp. (1963).

16. Ferenc Kárteszi (Cegléd, 1907-Budapest, 1989)

Teacher of mathematics and descriptive geometry, professor, Doctor of Mathematical Sciences

His first article The Tetrahedron was written while he was still in school, and was published in the Mathematical and Physical Journal for Secondary Schools. He attended to the University of Budapest (1925-1929). He obtained his diploma as a teacher of mathematics and descriptive geometry in 1930, when he was also appointed as an assistant at the Technical University of Budapest. Because of his increasing interest in teaching, he left, and began to teach in a secondary school in Győr (1931-1940). He made his doctorate in 1933, at the University of Debrecen.

His dissertation entitled On the ten conics determined by six points of a conic and the configurations connected with them was a brief one and had a French summary.

He spent the year 1936-1937 in Bologna, a town firmly attached to several Italian geometers. In 1939, he studied the Bolyai manuscripts in Marosvásárhely. During World War II, he was in military service and was a prisoner of war. In 1947, he became a professor at the Teachers' College. He habilitated in 1948 in the field of projective and descriptive geometry, and organized the teaching of descriptive geometry at the University of Budapest. He became Doctor of Mathematical Sciences. His areas of interest include: projective and descriptive 
geometry, finite geometry, and didactics. He wrote more than 120 articles and 11 books. His most important books are: An introduction to finite geometries and János Bolyai Appendix. The Theory of Space, with which he won the Award of the Hungarian Academy of Sciences.

His major works:

1. Descriptive geometry (in Hungarian), Bp. (1950, 1957, 1976, 1978).

2. Introduction to finite geometries (in Hungarian), Akadémiai Kiadó, Bp. (1972).

3. Linear transformations (in Hungarian), Tankönyvkiadó, Bp. (1974).

4. János Bolyai. Appendix. The theory of space, Akadémiai Kiadó, Bp. (1987).

\section{Summary}

Under the guidance of Professor Dávid, an excellent Mathematical Doctoral School was established at the University of Debrecen, with the aim to train the next generation of researchers with academic degrees. Many of the topics concerned are related to Dávid's projects, to his research of the Bolyais and that of the Gauss-type 'medium arithmetico-geometricum'. In our research, we find that most of the members of Dávid's research group became outstanding scholars or outstanding teachers of mathematics or physics.

\section{References}

[1] Debreceni Egyetem Rektori Hivatalának iratai: Doktori anyakönyvek, Adatfelvételi Lapok a doktori oklevél kiállításához, Eredeti diplomák betűrendes nyilvántartása, Felavatott doktorok törzskönyvei (1927-1941).

[2] A Debreceni m. kir. Tisza István Tudományegyetem Bölcsészettudományi Kara Tanácsának jegyzőkönyvei (1921-1945).

[3] Budapesti Műszaki Egyetem Gépészmérnöki Kar Geometria Tanszékének története, http://math.bme.hu/ szirmai/tansztor.htm

[4] Budapesti Vörösmarty Gimnázium Évkönyve, Budapest, 2006.

[5] Dissertationes Dávidianae, Debrecen (1927-1940), DE Matematikai Intézetének Könyvtára, 387 leltári szám.

[6] Kántor Sándorné Varga Tünde, A kitüntetéses doktoravatások története a Debreceni Egyetemen 1912-2013, Debreceni Egyetem, Debrecen (2015), pp. 549, ISBN 978-963-318-485-1. 
[7] Kántor Sándorné, Tudós matematikatanárok Hajdú, Szabolcs és Szolnok megye középiskoláiban (1850-1948), 2. javított és bővített kiadás, (2009), http://mek.oszk.hu/07200/07238, pp. 229, ISBN 978-963-06-7231-3.

[8] Kántor Sándorné, A matematikatörténet szerény apostola: Szénássy Barna (Ungvár, 1913. 12. 11.-Debrecen, 1995. 11. 12), Gerundium, Egyetemtörténeti Közlemények V (MMXIV) 1-2, 147-162.

[9] Kántor Sándorné, Dávid Lajos, Pedagógusok Arcképcsarnoka, Karácsony Sándor Neveléstörténeti Egyesület, H-B megye, Debrecen, 2002.

[10] Kántor Sándorné, Tóth Lajosné, Pedagógusok Arcképcsarnoka, Karácsony Sándor Neveléstörténeti Egyesület, H-B megye, Debrecen, 2003.

[11] Kántor Sándorné, Kárteszi Ferenc, Pedagógusok Arcképcsarnoka, Karácsony Sándor Neveléstörténeti Egyesület, H-B megye, Debrecen, 2008.

[12] Kántor-Varga, T., Biographies, A Panorama of Hungarian Mathematics in the Twentieth Century (Ed. J. Horváth) Springer-Verlag, Berlin-Heidelberg (2006), 563-607.

[13] MacTutor History of Mathematics archive: Lajos Dávid, http://www-groups.dcs.stand.ac.uk/ history/Biographies/David_Lajos.html

TÜNDE KÁNTOR

INSTITUTE OF MATHEMATICS

UNIVERSITY OF DEBRECEN

H-4002 DEBRECEN, EGYETEM TÉR 1.

E-mail: tkantor@science.unideb.hu

(Received April, 2018) 